\section{Society Proceedings}

Amerlan COMING MEETINGS

Aberlen Physlologleal society, Inaltimore, Ine. $27-30$

Fouthern Sublje Ifenlth Association, Ilavana, (cuba, Dre. 4-9.

Western surg. nnd Giynecol. Assn., Waslifngton, 1). C., Jece 12-14

AMER Su'g. and Gynecol, Assn., Kinsias City, Mo., ijec, 18-19.

\section{RICAN ASSOCIATION FOR THE STUDY AND PRE- VENTION OF INFANT MORTALITY}

The Pecond Anuual Afeting, held in Chicago, Nov. 16-18, 1911

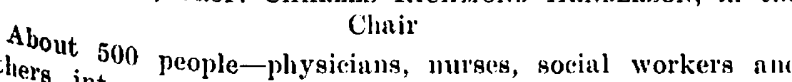
session. interested in infant welfure-nttended the opening Nursing The first mecting was a session of the Section on of Now and Social Work, over Which Miss Jillian D. Wald lork presided.

\section{Infant Welfare or Milk Stations}

Miss Minie Il. Aliress, of the Clicigo Infant Welfare pensary, Miss llakitel J. Ifwel, of the Cleveland Babies' Jisthe milk and Hospital, and Mrs. IV. II. BAltros, supervisor of City, read stations of the depurtment of health of New York pripers on this subject.

\section{DR, Gisctission}

S. Y.: Georae W. (AoLER, lienlth commissioner of Rochester, instead Ias not the time come to attack the milk stations We have supporting them? In building up milk stutions, the legal ben losing sight of the fuct that the real duty of is safe authorities is to compel the production of milk that upply to be uned by everyone, as the milk stations at best Cities only a small portion of the clean milk that is neceled. compel, and no longer have laws that soothe but laws that Infant, and their enforcement should be insisted on.

Mortality from the Point of View of District Nursing giving $\mathrm{MI}$. LOANE, through Miss foley, presented a patper nursing the conchusions from severnl yeurs' experience in district in inf in various parts of Einglund and diseussing the rasult $b_{a d}$ hous mortality of illegitimacy, reckless marringes and due to poyg, showing that the waste of infant life is mot all

Cooperation in Nursing and Social Work
Miss Higarss, secretary of the Associated Cliarities of 13os. good The tusk of a nurse is to make healthy citizens of good citiacter; the task of the social worker is to make tors anl citigens with henlthy bodies. The time was when docon to the medical group thought they could plaster luealth with the individual; now they find that they must work workers Nure-exercise, fresh air, good food, etc. The social to benefit trying to present an opportunity for the peoplo suasion themselves and are using encouragement and per. chajged thee that the opjortunity is taken. They lauve social their methods, but the doctors, the nurses anil the bring theikers lave not recognized that these clianges should thought more closely together. If the social workers have of the of the community too much, doctors liave thought in Bostommunity too little. After five years of cooperation them in the loctors have said that the social history helps treatment. nical diagnosis. Social work is also of value in pitals or. Social workers can have children sent to the loos. doctorg persuade people to have operations done which the afler.car could not do. This work. is also valuable ill the trying to. The doctors and the social workers have been has not find a disease that has no social significance, but it disenses, been found. Surgery, tuberculosis, debility, venereal mothers alcoholism, all have their social significance. of cent. wero who parents had been total ubstainers, 01 per fathers able to nurse their infants; of mothers whose to nurge; been moderate drinkers, 88 per cent. were able per cent of those whose fathers were heavy drinkers, 31 fathers were able to nurse their children and of those whose their children.

\section{DISCLISSION}

3)i. Hexiry B. Favill, Chicago: 'l'he medical resources known to the worlel are not sulliciently available to the poor. The difliculty is that the machinery of society has broken down at the point of contanct of acquired scientifie knowledgo and its appliention to the mass of the people. This is nobody's fault in particulur. $U_{p}$ to recently the agency of administration of medical relief by which was includer, advice, etc., has been the local pliysician, who, in that respect lans not been a suceess. Many reasons have contributed to this unfortumate fuct-the ignorance of plyssicians, the mulitude of struggring, low-grade physicians, and lack of intelligrence and educution among the people.

\section{Visiting Obstetric Nursing}

Mirss Canoly C. VAN Brancom, executive secretary of the Committee on Prevention of Blinduess of the New Jork Association for the Blind: The problem of infant mortality is to be solved through intelligent motherhood and the keynote of the work is to teach mothers how to are for them. selves and their infants. Fifty per cent. of births in this country are attended by midwives who are mostly untrained, ignormit woinen, and much umecessary death, blindness and mental and physical degeneracy result. In England, through the laws creating the Central Midwives Joand muel improvement lius resulted in infunt mortality and morbidity. In this country, midwives are neither trained nor supervised, although in New York City a truining school has been sturted in connection with Jellevue lospital and an attempt has been mate to register midwives.

\section{DISCUSSION}

Dr. Racilelte S. Yarros of Chicago: The midwife camnot be abolished at the present time. A large proportion of the women of foreign birth demand midwives. 'The thing to do is to improve the quality of the milwives, possibly by hav. ing obstetric nurses or other trained nurses with normal eatses. A great need is for the attendance of either plysi. cians or trained nurses at modernte fees for the great midalle class.

\section{Other Papers}

Among other pupers rend at this meeting were "l'he Rela. tion of District Nursing to Infant Mortality," by Miss AMY Iluanss, general superintendent of the Jubilee Institute for Nurses, London, Jung. This paper was read by Helen Scott llay, superintendent of the Illinois Training Sehool for Nurses; "Rural Problems in the Prevention of Infant Mor. tality," by Miss Jula Philites Crandall, Columbia University, New York, und a puper on "Maternity lospitals," by Miss Martira M. Russibi, of Slone Maternity llospital, and Mlis. Reginald Fostrer of Baltimore.

In the evening session, which was really the opening ses. sion of the meeting, the president of the association, Professor Ilenderson, read his iddress.

\section{The Interests of Society in the Protection of the Mother and Child}

Pros. Chandes R. Hunmerson, Chicago: We are not foumding a new society but promoting the oldest human social group: the mother and her child, which is more primitive, more fundamental than any other institution in society. First of all, the mother las ler rights for which we must stand and invoke all the fores of the constitution, laws and gov. ernments. She has the right first to a home, and we must improve our economic conditions so that alie may receive udequate support and be surrounded by such physical conditions as to preserve her own health and that of her child in the home as well as in industrial occupations. Before and after confinement she must have rest and must be provided with the necessary menns to procure it. Hitherto she hin. had no resources but charity and the results of scant thrift. and some form of insurance must be found for the deserving cases. The buby has moral riglits which should be trausferred into legal rights. It has the right to be registered and from the time it is born through all its life it has a right to its name and place in eitizenship, for without these all 
its other rights are lost or rendered uncertain. They cannot be muintained unless there is registration at the time of its birth. The child of the unmarried nother and the mother herself should be protected by all the power of legis lative organization agninst the neglect of the father, who ought to be songht to the ends of the earth and brought back to the task of supporting the child. The charitable and public and private associations can do much. What we need is someone who is responsible for every dependent child and who stands with the power of the courts back of him to interpret his duty to see that the task is performed to protect the baby's rights. Society also has rights. Eugenies stunds for the rights of society, for the rights of the mothers to be healthy and for the rights of the infants to be well born. Society's rights are for the future. The rights of posterity must be protected. Society must linve something to say about those who should not be born.

\section{Municipal Measures Against Infant Mortality in Chicago}

Dr. Geonge B. Youna, commissioner of heulth of Chicago: Most of the measures in Chicago directed agranst infant mortality have been aspirations rather than achievements. Conplete and accurate registrution of births is absolutely neces. sary before any renl beginning ean be made to study the causes and the means of preventing infunt mortality. At present, 17 per cent. of the milk coming to Chicago is illegal milk, as it is neither pasteurized nor from tuberculin-tested cows. Eforts will be made to amend this and if free milk camnot be provided then the milk obtuinuble will be as good as can be obtained under ordinary municipal regulation. The methods employed do not try to prevent largely, but try to correct; this is a vital fundamental error; but along lines of correction something has been done; a start has been made in the work of eliild hygiene. In the beginning, fifteen nurses were provided and they joined lunds witl various associntions for infant welfare alrendy established in the eity and better results were obtained by reason of this cooperation. Enougl nurses to cover twenty-five of the thirty-nine wards of the city have been provided but in only ten was intensive work done. That this work mens something is shown by the fact that the nurses made 38,335 culls and 20,041 revisits. As the result of this work in the last year the reduction in the deaths for the three months, July, August and September, as compared with the year before was 362 , of which 311 oceurred in the wards covered by the visiting nurses. The diminution in the death-rate was much better in the wards covered intensively. 'The reduction was 25.41 per cent. as against 15.5 per cent. in the other wards. Various means of an educational nature have been employed in the way of posters in the diflerent langunges, leaflets, moving picture shows, ete., and following the lead of New York we have started Little Mothers' schools in which it is attempted to teach the elements of infunt lyygiene and care of the baby. It is expected to innugurate forty-eight of these schools soon. Mothers' conferences have also been begun in the congested foreign districts where the mothers can come and consult the physicians who lecture and explain matters. The health department is willing to do everything possible but it is up to the citizens to say whether the work shall be given proper financinl support.

\section{The Illegitimate Child}

DR. H. Hastings Hart, director of the department of Child Helping, Russell Suge Foundation, New York, presented an eluborate, constructive plan for the prenatal aud postnatal care of these infants and their generni supervision up to the time of their becoming self-supporting citizens.

In the section of Eugenies, in which great interest was manifested, a number of papers were read and resolutions on certain subjects were reported to the general meeting at the afternoon session.

\section{Eugenics and Infant Mortality}

Mr. Roswelr. Jornson, Bartlesville, Okla.: The movement for universal infant conservation is in direct opposition to the action of natural solection, but no discriminating measures are at present justifinble. The eflorts against infant. mortality must be continued. Sexual selection and fecundal selection must take the place of natural selection, the units should be based on worth and fitness for parenthood. Parilies. of superior stock slould be encouraged to have large families We must look to the physician mainly to exert the prope influence in the interests of sexual and fecundal selection.

The Hereditary Effects of Venereal Diseases and Their Rela-

tion to Infant Mortality
1)R. Prince Monuow, New York: The problem of infant mortality is as much, perhaps more, a biologic than a met the problem. Envirommental conditions are important, but the dominant influence must be assigned to the hereditary make up of the individual. The social diseases have a speclly significance in relations to eugenics in that they specificals alleet the system of generation, producing a race of beings, on account of a lack of "biologic capital."

Hereditary Tuberculosis and Infant Mortality

l'rolr. H. E. Jordan of the University of Virginia: Tho inheritance of a predisposition or tuberculoug dinthesis is an inheritance of a predisposition or tuberculous diat of certain
important fact. There is no basis for the dogma of in this health lengues that tuberculosis is not hereditary in that sense. Prof. Karl Peurson furnislies most cogent proof than the phthisical diathesis is just as hereditary as any humant characteristic we know about, and that it is more importanter than direct infection in families. Despite the vastly great as opportunity for direct infection between husband and win the against brother and brother, the correlation coellicient in the former case is not more than 0.17 or 0.25 maxinum, while int the latter it is from 0.40 to 0.50 . The further fact that abone 38 per cent. of all tuberculons patients in sanatoriums comis. from tuberculous families is also significant of the transm sion of a predisposition to the discase.

The section on Midwifery was presided over by Dr. Mary Sherwood of Baltimore.

\section{The Midwife Problem and Medical Education}

Du. J. Wultruge WiLliams, professor of obstetrics in Jolus Hopkins University, presented a paper which the read by Dr. Frank W. Jynch of Chicago. Dr. Williams astions result of replies to a questionnaire containing fifty questiong. sent to tenchers in obstetrics in the medical colleges throut a out the country draws some conclusions which constitute severe arraignment of the methods and results of tenchin Til
obstetrics in this country. The paper will appeur in JoUinal.

Dr. Joserin DeLee, Chicago: The indietment of the medical schoels by Dr. Williams is true, but the principal the is a mutter of noney. The public does not respect obstetrician and will not pay him adequately. His stanideris not so high as that of the surgeon. This lack of considation for obstetries extends through the hospitals and mat icul schools and the young men will not become either obsology. riciuns or teachers, but go into surgery and gynecolo of which are better paid. The elevation of the standard sols obstetrics in the opinion of the public furst and in the seter afterward is the demand. When the women demand a better stalsdurd of service and cease employing midwives betn service will be provided. This education of the woment the be ussisted materinlly in the women's clubs throughout estabcountry. Maternity hospitals of high class must be es call lished more universally in which nurses and plyysicians naturily be pructically trained in obstetries. abolish the midwives.

DR. Rachelle S. Yabros, Chicago: The conclusions of $\mathrm{Dr}$. Williums were true, but the public must demand good wore and it will gret it. The midwives, objectionable as they are, cumot at present be abolished, I believe; but if they ares then lying-in hospitals must be estublisled where the expenthe is not grent and the women educated to go to them in they instances, chiefly among the foreign population, in which thes now demand midwives. As a measure of expediency and an improvement over the midwife I recommend the educa work of the trained nurse to take care of normal cases, or to as assistant with the obstetriciall. 
Dr. Fraxk Lxincu, Chicago: I believe that a little explana. to an some of the conclusions of Dr. Williams is needed schools audience composed largely of laymen. In the medical medicine this country there are men of all grades. Real (iood suregan, it might be snid, only about sixty years ago. This surgical work began as recently as twenty yeurs balck. old and making a summary of obstetrics, includes the men the youmg teachers and obstetricians, and the young stateme in the better position. The paper is true. but the intoments must be qualified. Nos all graduates go directly. One sehactice; many go into hospital work and get experiene's. pital nool in chicago practically insists on a year of loonpublic knork, for which they give a degree of honor. Until the good obstews how to choose a physician there is no hope for not opstetrical teaching. What is wanted is trained men, properly equingooms. The way to get good tenching is to pily has equipped men for teaching the young physicinns.

\section{Has the \\ Trained, Supervised Midwife Made Good? Shall Mid.}

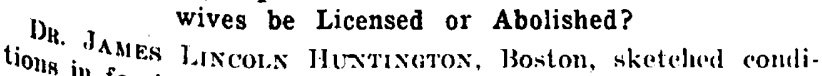
tions in foreign countries where they have traned, supervised said to bes in England and cermany, where the rosults are midwifor be unsatisfactory. Amerioa fus no luws concerning The Bery, but they should be abolished and not licensed. by the pon lying-in hospital with out-patient service, assisted problem.
public and social workers, seems to lave solved the
and

Mins, Discession

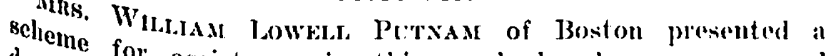
described assistance in this work by lay women, and Boston. Mini,

pensary. Upllas of the Clicago Jying-In llospital and Disnbout also described the work done by an orgatization of lines. 500 Chicago women in an educetional way along these

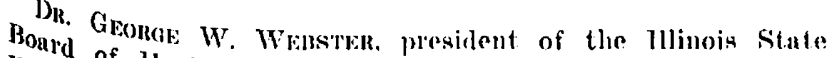
Feleration lienlti: I culled the attention of the National Dr. Willin of state Bourds, in 1!04, to the facts disclosed by amolnts to The time deroted to obstetries in some scluow: devoted to 350 hours. There are schools in which the time sixty ho obstetries in the entire four years' course is only laving hours. There are only thirteen states in the Union of midwive in any way governing the licensing and control visions of thes. In fourteen states the law say that the pro. In all of the medical practice acts shall not apply to thom. (o) vineed states the laws are silent on this subjert. I am question that the question is not wholly un educational of a mion, but an economic question. In Clicago the servires: as good wife may be obtained for $\$ 2.50$, and if the service is cannot be that of the physician, as Dr. Williams says, they sometloing blamed for accepting the service. We must supply midwives good at an equally low price. We cannot legislate 'runkes out of existence any more than we can poverty, D). Evess or rrime.

of a midws, New York: The average cost of the attendance witl midwife in New York is from $\$ 5$ to $\$ 10$. Contrast this pensaries. service rendered by the lying-in hospitals and dispay for betthe 50,000 births attended by midwives would of this mater service for the whole eity aud allow of the use aterial for teaching purposes.

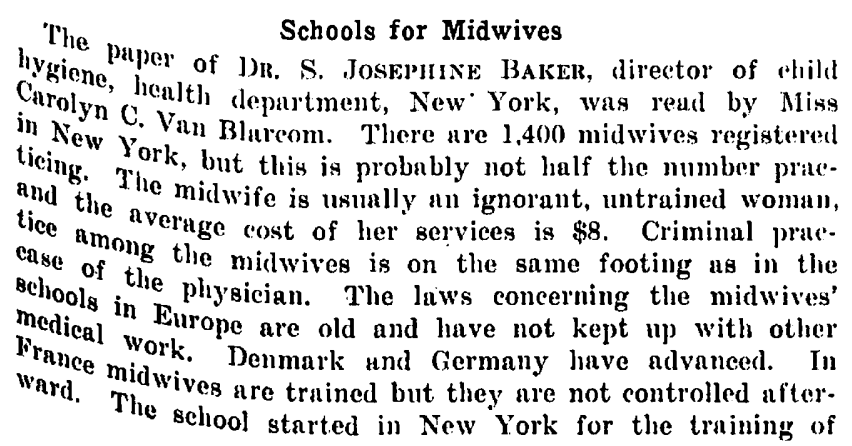

midwives, in connection with Bellevne Hospital, has a six. months' course, three months of which ure spent in the house whore the midwives are taught obstetrienl nursing, how to malie a diagnosis, the principles of breast-feeding. cleanliness, ete. The second three months are spent in the homes of patients, where under the supervising nurse or the physician the midwife is taught to apply what she has learned in the sehool. The idea is to entablish more of these schools and legalize their rogistration and licensing hy the state.

DIscetsion

Miss C. Vax Bhakcom, New York: I do not agree with Dr. Iluntington and Dr. Lee; I believe that the linglish system js going to make for better health of the children and their molleers. I have just returned from a study of the working of the system there. The sentiment there is in favor of training midwives. The movement was started by the london Obstetricul Society thirty yours ago, which is significant. It has the support of all the expresidents of the Royal Obstetrical Society. of Dr. Oster and otbers. The question is one of better eare. Two staniards of obstetries are not desirable. 'Tlie object is not to invade the province of the dertor, but the problem is one of sesuring adequate attention ant care.

Der. C. S. Bucos, (hicago: I believe if it is possible to abolish the midwives it would be well. In America each state call institute experiments and the whole country en prolit by them. Whatever muy be dome in Boston or in Massaclusetts, I believe that in New York and Chichno the abolition of the midwife is absolutoly impossible. As to mirlwife selools, if this matter is not to be allowed to go without "IIy uttention, there mist be celoonls for midwives. It is dombtful whether the medienl colleges can go into this work, hut " nuversity, which has its mediend and other departments, (ain properly liuve a department of milwifery.

1)r. R. S. Yambos, (hicago: It is important to have something lone for the benefit of the people who camot have regular physicians but must have midwives. It is not alone " question of elevating the standard of obstetrical tenching.

Dr. J. W. SenkresculewskY of the U. S. Public Henlth and Mlurine-llospital service introduced a resolution, which was adopted by the section, to the elfect that the teaching of obstetrices in the United States is at present inudequate and that no time should be lost in elevating obstetrics to the importance at least accorded to melieine and surgery; inves. ligntion of local midwife conditions was urged as a menns of obtuining information; that the extonsion of ontdoor obstetrical service be alvocated as a method of preventing discolse and a high mortality-rate.

$$
\text { (To be continued) }
$$

\section{UTAH STATE MEDICAL ASSOCIATION}

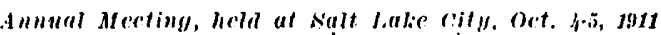

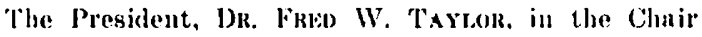
The Bacteriology of Diphtheria

DR. R. IV. Asuley, Salt lake City: In diphtheria the earlier the diagnosis the better for the patient and the community. A. culture taken from the thront will in twolve hours, often less, clens up the diugnosis and indiente the treatuent necessury. During the past year in Sult Lake City 25) por cent. of all cuses of diphtheria on record nt the board of liealth were discovered by the examination of cultures taken from the thronts of children, previously ill, and seeking to obtain permits to return to school. The diagnosis in each case, previously made by the attending pliysician, was "sore throut" or "tonsillitis." Ellective quaruntiue in all cuses slould bo regulated by bacteriologic examiations. and every patient infected sliould be isolated until the bacilli have entirely disappented. In the average case this requires about two weoks. Mild rases do not always remuis mild, and every year many children die of diphtheria while being treated for "sore throat" or "tonsillitis." Jvery case of sore thront should be looked on with suspicion, as a contugious disease, intil it is proved otherwise. Cultures taken from the thronts 